\title{
A Systematic Review of Augmented Reality in STEM Education
}

\author{
GLORIA AJIT ${ }^{1}$, TERRY LUCAS ${ }^{2}$, RINGAH KANYAN ${ }^{3}$ \\ Faculty of Applied and Creative Arts, UNIVERSITI MALAYSIA SARAWAK. \\ ${ }^{1}$ Email: gloriaajitfrancis@gmail.com \\ 2Email: Iterry@unimas.my \\ 33Email: kringah@unimas.my
}

\begin{abstract}
This study presents a systematic review of the existing literature on the benefits and challenges faced regarding the use of augmented reality (AR) in Science, Technology, Engineering, and Mathematics (STEM) education. Guided by the Preferred Reporting Items for Systematic reviews and Meta-Analyses (PRISMA) method, a systematic review of the ScienceDirect database identified 19 related studies. Further investigation of these articles resulted in four themes of AR advantages, namely its contribution to learners, the learning outcomes, the interaction of $A R$, and other benefits. These four themes further produced a total of 16 sub-themes, while the challenges aspect of AR resulted in 5 sub-themes. The most reported benefit of AR is that it stimulates learning achievement. Some observed that the challenges imposed by AR are concerned with marker detection and usability. Several other problems and advantages of AR usage in STEM education were also discovered, which will be discussed in detail. Additionally, the existing gaps of AR study in the STEM education field were identified, and recommendations are therefore presented for future research.
\end{abstract}

Keywords: STEM, Augmented reality, systematic review, education

Classification JEL: A10, A21, A22, A23, A29

Recibido: 2 de Diciembre de 2020

Aceptado: 14 de Diciembre de 2020 


\section{Introduction}

Interest in educational models of science, technology, engineering and math (STEM) is drawn across the global educational landscape. Increasing academic skills in STEM discipline has also become a national priority to ensure that students are well-prepared and eligible for STEM career (Thibaut et al., 2018). Higher STEM education is achieved by increasing student interest in STEM since school years. However, past studies showed disfavours towards STEM discipline as students find it challenging to use their reasoning skills in an abstract representation of scientific concepts that require high spatial visualisation to master (Milton, Flores, Moore, Taylor, \& Burton, 2018; Sahin \& Yilmaz, 2020). Low conceptual knowledge on STEM disciplines, coupled with learning through memorisation complicates the development of students' thinking skills (Ali \& Bakar, 2019; Malhi, 2019; Pirttimaa, Husu, Metsa, Metsärinne, \& Metsa, 2017; Umi Fairus Mohd Jamil \& Fazlinda Ab Halim, 2018).

To fully capitalise on our students' STEM potential, educators must streamline STEM education and enhance their pedagogy. Previous research supports grounding this education and training in STEM pedagogy through an interdisciplinary approach and leveraging new technologies to assist processes of learning (Conley, Atkinson, Nguyen, \& Nelson, 2020; Sahin \& Yilmaz, 2020). As new technologies have emerged in recent decades allowing a more thorough exploration of suitable technology to assist STEM learning, immersive technology such as augmented reality (AR) has gained attention in recent years, with an increasing number of studies published in educational setting (Garzón \& Acevedo, 2019; Sirakaya \& Sirakaya, 2018).

AR technology involves overlaying digital information on a displayed registration, either dependent on the location or the perspective of an operator, into the existing environment. The overlaid virtual elements to the real environment enhance our senses as we can see and also feel the appeared information, which are any materials that can be digitised, for instance, images, audios, and threedimensional (3D) models (Garzón \& Acevedo, 2019; Sirakaya \& Sirakaya, 2018). The integration of AR in STEM education will add information to the real object or place that visualises either with mobile devices or computers so that students can observe details related to the object that was digitised.

The interactive digital content of AR makes learning more meaningful and enhance performance (Cai, Chiang, Sun, Lin, \& Lee, 2017; Cheng et al., 2019). Students can visualise and understand concretised abstract concepts (Laine, Nygren, Dirin, \& Suk, 2016; Moorhouse, Dieck, \& Jung, 2019). Combination of animation elements attract the student's attention (T.-C. Huang \& Lin, 2016; Safadel \& White, 2019), and consequently led to increased motivation (Chang \& Hwang, 2018; Erbas \& Demirer, 2019; Khan, Johnston, \& Ophoff, 2019) and interest (Wang, Lee, \& Ju, 2019; Yu, Sun, \& Chen, 2019) in the topics and the subject being taught.

While AR research in various educational disciplines has greatly advanced, however, it has not always been clear how these researches can translate into the classroom and assist STEM educational practices. Specifically, a better understanding of the AR technology basis in STEM and organised student-centred learning will play an important role in developing learning activities that allow students to comprehend basic STEM conceptual and procedural knowledge.

\subsection{Towards a systematic review framework on AR in STEM education}

A systematic literature review is a scientific method of obtaining all available data in compliance with certain predefined requirements to address a particular research question (Gough, Oliver, \& Thomas, 2012). Systematic and precise methods classify, select and critically analyses multiple research studies or documents (Tikito \& Souissi, 2019). Systematic research has advantages over conventional literature reviews as it improves review consistency, replicability, reliability and validity (Xiao \& Watson, 2019). A systematic analysis may explain the authors' claims of rigour in their report, allowing gaps and directions to be defined for future studies.

Though AR studies have been comprehensive in STEM education, attempts to systematically review these studies are still lacking. Several systematic reviews have been conducted in the context of 
education in general (Akçayır \& Akçayır, 2017; Altinpulluk, 2019; Bacca et al., 2014; Dey, Billinghurst, Lindeman, \& Swan, 2018; Korucu, Usta, \& Yavuzaslan, 2016; Saltan \& Arslan, 2017) and less focused on specific areas such as STEM. Limited studies were conducted within the framework of AR in STEM education (M. Ibáñez \& Delgado-Kloos, 2018) as the available literature ranged from AR trends in education (Altinpulluk, 2019; Bacca et al., 2014), uses and benefits (Diegmann, Schmidt-Kraepelin, Van den Eynden, \& Basten, 2015; Korucu et al., 2016; Saltan \& Arslan, 2017), theoretical and empirical foundations (Sommerauer \& Müller, 2018), AR game-based learning (Pellas, Fotaris, Kazanidis, \& Wells, 2019) and AR-based educational technology evaluation (Silva, Teixeira, Cavalcante, \& Teichrieb, 2019). Hence, this article aims to fill the void understanding, describe and characterise AR implementation in a STEM classroom.

This research is significant as there is a lack of systematic review consensus on the integration of AR in STEM learning and teaching. Furthermore, this study is essential because the declining interest among students in the STEM discipline will lead to decrease in the number of qualified STEM professionals in the global market (Wan Jaafar \& Maat, 2020) and thus trigger an urgent need to adapt and incorporate effective intervention strategies to resolve student interest and performance issues in STEM education. Immersive technology as AR has ample potential in STEM classroom, particularly when the subjects taught are new and difficult to visualise. Therefore, specifics of where the peerreview literature has so far centred provide an opportunity to understand where the emphasis is and where attention needs to be focused.

For a relevant systematic review, the current article was directed by the main research questions: (1) What are the general characteristics of AR in STEM education? (2) What are the benefits of AR in STEM study?; and (3) What are the challenges of AR in STEM study? In this study, we discuss the connection between AR technology and its benefits when applied in STEM education to promote learning, as well as suggesting new research possibilities that await exploration. More specifically, exceptional attention was given to STEM education as this discipline is predicted to benefit significantly from the integration of immersive technologies such as AR due to the nature of the abstract conceptual representations and terminologies (Hayes \& Kraemer, 2017) of STEM subjects.

\section{Methodology}

The study adopts Preferred Reporting Items for Systematic reviews and Meta-Analyses (PRISMA) as a guideline to systematically identify and critically evaluate relevant research covered in the study (Moher, Liberati, Tetzlaff, Altman, \& Group, 2009). PRISMA is used to answer the research questions following a four-step process: identification of related keywords, screening, eligibility, and data abstraction and analysis. Although often applied within medical research, PRISMA guideline is currently used regularly within the social science field (e.g., Askari et al., 2018; Lai \& Bower, 2019; Saltan \& Arslan, 2017; Wilhelmsen \& Sørensen, 2017) since it specifies the research questions towards the need for a systematic review.

The review identifies relevant published articles on the ScienceDirect journal database based on its relevance to the AR in STEM education domain. ScienceDirect is a large database of scientific and medical research with full-text search coupled with organised topic areas subscribed by virtually every university (Gies, 2018) and can also be used as a principal search system, and it is well-suited to support the synthesis of systematic reviews (Gusenbauer \& Haddaway, 2020). ScienceDirect journal database has been used in the review of educational research (Petri \& Wangenheim, 2017; Sharma, Torrado, Gómez, \& Jaccheri, 2021; Shiner, 2018) in order to systematically select relevant articles.

The systematic review process started with the identification of keywords, which was performed on May 2020 through the following search string suggested by Sirakaya et al., (2020): "augmented reality" AND (STEM OR science OR technology OR engineering OR mathematics), adding "AND education." Next, the screening of articles is performed based on agreed criteria, which includes studies with empirical findings, articles reported in English, and materials complementary to AR and STEM fields (Table 1). 
Table 1. The Screening Criteria

\begin{tabular}{|c|c|c|c|}
\hline Criteria & Document type & Language & Nature of the study \\
\hline Inclusion & Article with empirical data & English & $\begin{array}{l}\text { Articles focusing on AR } \\
\text { and STEM education }\end{array}$ \\
\hline Exclusion & $\begin{array}{c}\text { review articles, book } \\
\text { chapters, conference } \\
\text { abstract, articles without } \\
\text { empirical data }\end{array}$ & Non-English & $\begin{array}{c}\text { Not focused on AR and } \\
\text { STEM education }\end{array}$ \\
\hline
\end{tabular}

Then, the remaining articles are meticulously examined in the eligibility stage to confirm that the inclusion criteria are met. In short, 59 articles were assessed for eligibility, of which 19 were eligible for review (Figure 1). The remaining 40 articles that were not associated with STEM education are excluded. A total of 19 relevant articles were reviewed to determine appropriate themes and subthemes, parallel with the formulated research questions. The suitable themes and sub-themes were identified, resulting in four themes, which are a contribution to learners, the learning outcomes, the interaction of $A R$, and other advantages.

Figure 1. Research Flow Diagram

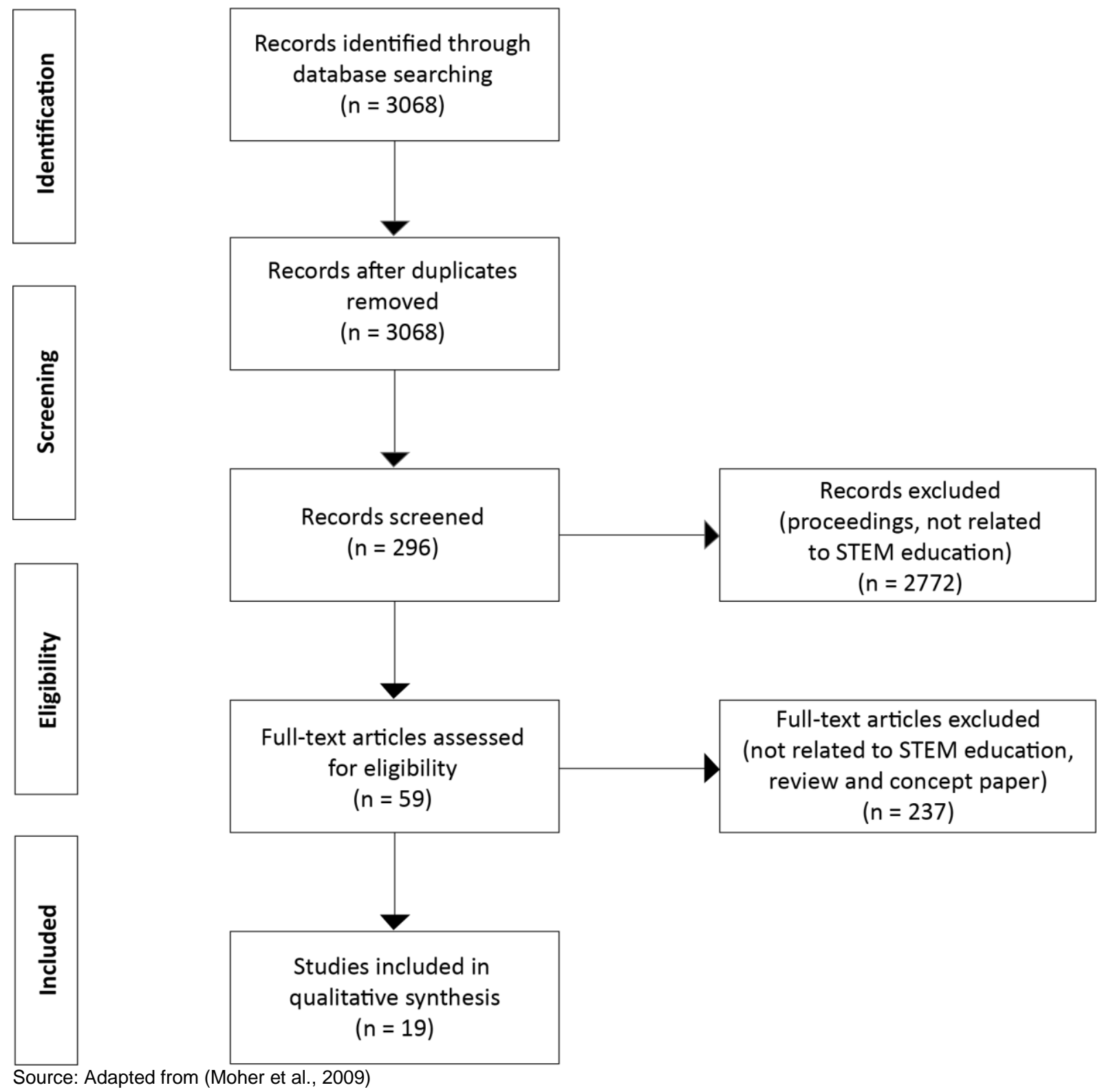




\section{Findings and discussion}

The results relevant to study characteristics, classification of the evidence base, and thematic analysis are presented in this section.

\subsection{Characteristic of AR in STEM Studies}

The review recorded 19 relevant articles that are relevant to the research questions, which were published from the year 2012 until May 2020. One study published in 2012 (5.26\%), two studies in 2013 (10.53\%), five studies published in 2014 (26.32\%), one study in 2015 (5.26\%), two studies published in 2016 and 2018 (10.53\%), one study in 2019 (5.26\%) and five studies published up to May 2020 (26.32\%) (Figure 2). According to the Horizon Report, AR is one of the emerging educational technologies with significant advances (Brown et al., 2020), and the studies complementary to this evolving technology are expected to increase in the coming years. Regarding journal type, six of the reviewed articles (31.58\%) were articles from Computers in Human Behavior, while $68.42 \%$ were from Computers and Education.

Figure 2. Study on AR in STEM education published by year

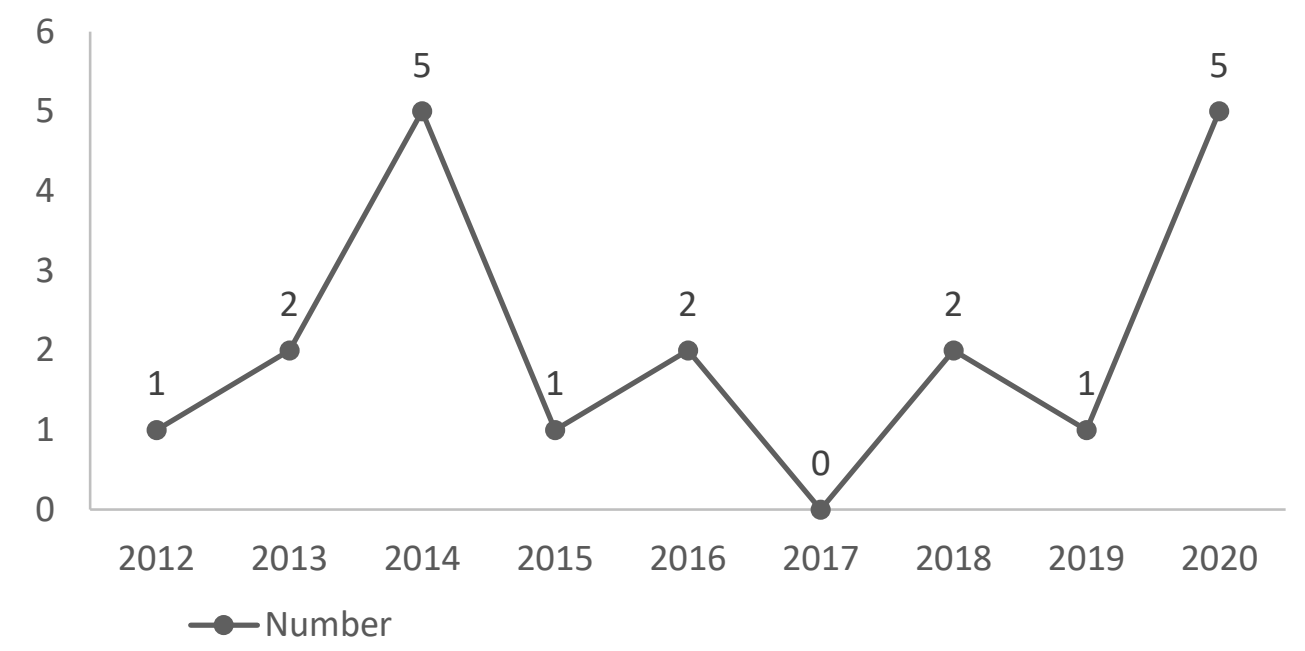

The materials that were assessed referred to the adoption of AR technology in STEM-related subjects from four continents, including Asia (36.84\%), North America (21.05\%), Europe (36.84\%) and South America (5.26\%) (Figure 3).

Studies ultimately showed that the common sample groups are secondary school students $(45.45 \%)$, followed by students in primary school $(27.27 \%)$, undergraduate and graduate students $(22.73 \%)$ and teachers (4.55\%) (Figure 4). From this result, it is clear that most of the reviewed articles were focusing on the K-12 level (72.72\%). Similar results were also achieved by Akçayır and Akçayır (2017) and M. Ibáñez and Delgado-kloos (2018), which concludes that most of the samples in ARrelated articles are K-12 students. K-12 students are the most preferred sample groups, possibly because, based on Piaget's developmental level, children in primary and secondary schools are in a stable phase of operation (Kohler, 2014). At this stage, children can comfortably learn more about concrete concepts through classification and reasoning across sensory organs (Ghazi, Ullah, \& Jan, 2016). Hence, learning tools such as AR will make it easier to concretise abstract concepts which are necessary during this phase.

The AR in STEM review shows that the common sample size was between 101 and 200 (26.32\%). Other articles reported sample sizes between 41 and 60 (21.05\%), 21 and 40 (15.79\%), 61 and 80 (15.79\%), 81 and 100 (15.79\%) and between 201 and 300 (5.26\%). Unlike data from previous studies, the study showed that the most common sample size reviewed was between 31 and 100 (M. 
Ibáñez \& Delgado-kloos, 2018; Sırakaya \& Sirakaya, 2020). This result may be a direct consequence of the methodology of that particular study, which was mostly an experimental method.

Figure 3. Study on AR in STEM education according to continent

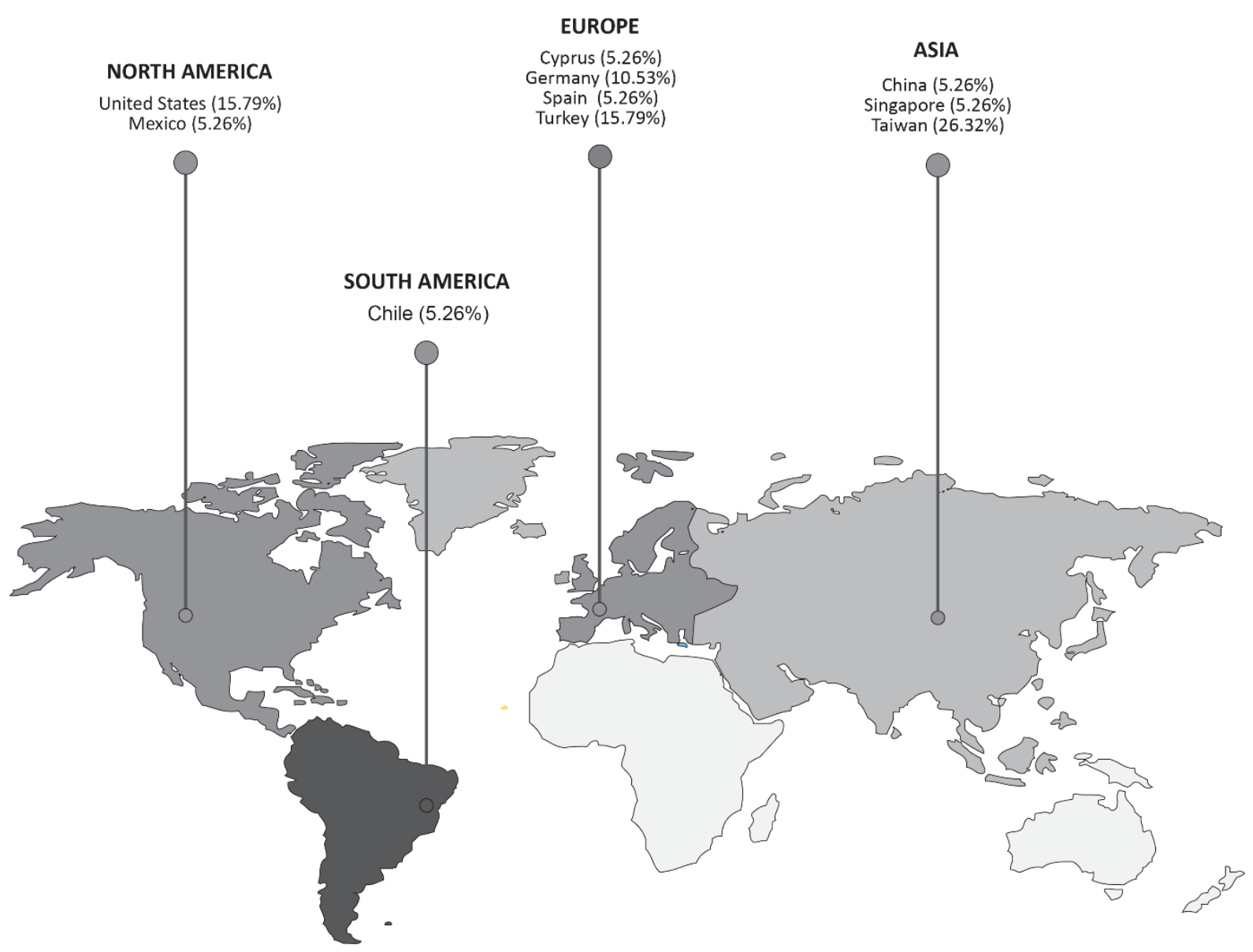

Figure 4. Sample Groups

Teachers

4,55

Undergraduate / graduate students

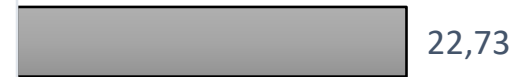

Secondary school students

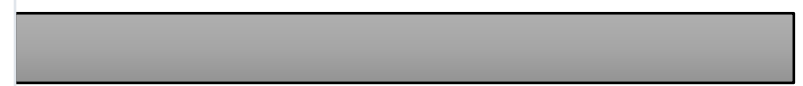

45,45

Primary school students

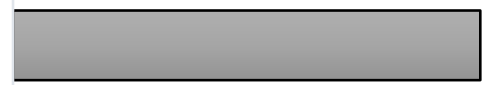

27,27

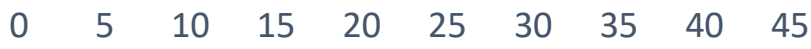

50

Percentage 
AR in STEM education is conducted in various STEM fields such as Physic (31.58\%), Natural Science (26.32\%), Mathematics (15.79\%), Chemistry and Astronomy (10.53\%), and Science (5.26\%). On the other hand, it was found that ten studies (52.63\%) were carried out in classroom settings, three studies $(15.79 \%)$ were conducted in virtual laboratories, four studies $(21.05 \%)$ were performed on field trips, while two studies (10.53\%) were conducted in museum settings. These results agree well with existing reviews on class-context as the most preferred educational context (Figure 5) in AR and STEM study (M. B. Ibáñez \& Delgado-Kloos, 2018). Although class-context is preferable among AR studies, Garzón and Acevedo (2019) reported that informal settings produce better learning outcomes than formal settings. Thus, this indicates that teachers need to be encouraged to integrate interactive technology as AR in everyday activities instead of just using AR applications within the classrooms.

Figure 5. Educational Context of AR and STEM Study

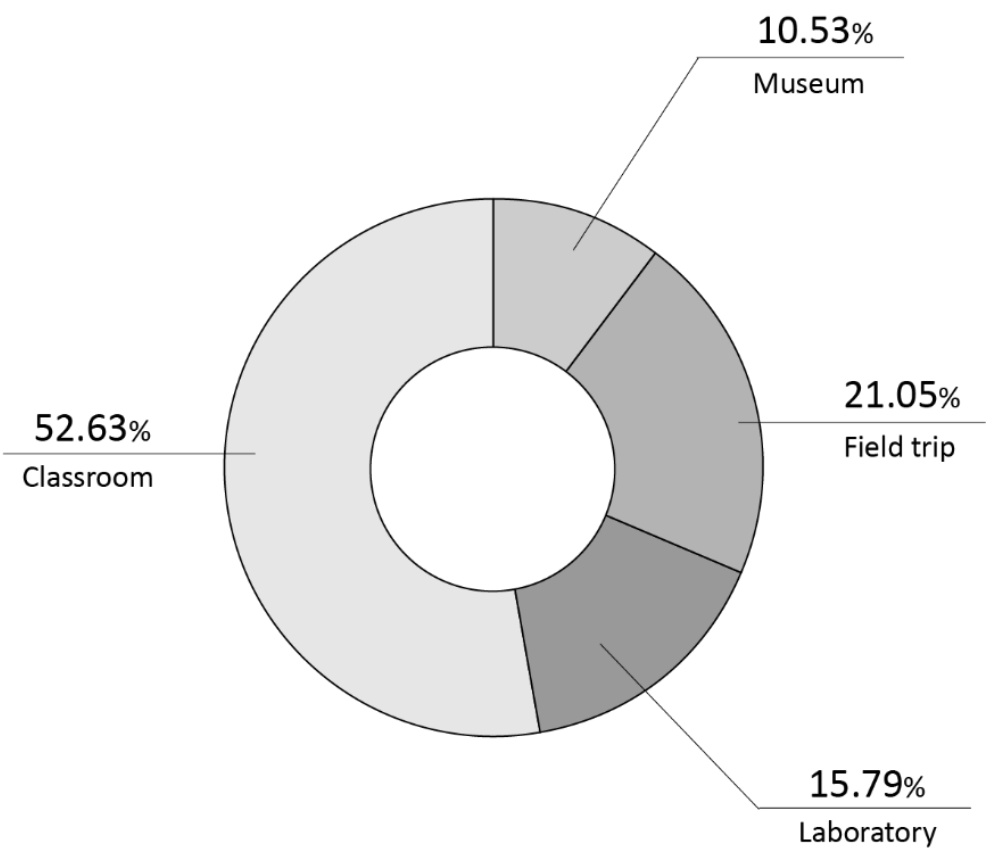

The most convenient and frequently used tool in the findings were achievement test (34.21\%), survey/questionnaire (28.95\%), interview protocol (15.79\%), Flow State, Attitude, Cognitive load or Usability scale (10.53\%), observation (7.89\%) and other (2.63\%). Survey and achievement tests are the most preferred tools in conducting studies on educational technology, consistent with Sirakaya and Sirakaya (2018).

Based on type, 13 of the studies included marker-based AR, while five studies include locationbased AR (Table 2). Among 13 marker-based studies, nine studies utilised handheld display in five application type. The five studies include simulation-based game (Echeverría et al., 2012), exhibition (Sommerauer \& Müller, 2014), problem-based simulator (Ibáñez et al., 2014; Fidan \& Tuncel, 2019), flipped learning AR (Chang \& Hwang, 2018), collaborative learning simulator (Chen \& Liu, 2020), while another three studies application type is unspecified (Akçayir et al., 2016; Conley et al., 2020; Ibáñez et al., 2020). Three marker-based studies incorporate desktop/laptop displays (Cai et al., 2014; Lin et al., 2013; Sahin \& Yilmaz, 2020) while Thees (2020) utilise HMD in their study. Meanwhile, all five location-based studies use handheld displays. The most mentioned application types of AR use in STEM studies are inquiry-based simulator and problem-based simulator. Based on the review, intervention that uses location-based AR are conducted in Natural Science subject while the marker-based are widely used in Physic and Mathematics. Marker-based AR was preferred compared to location-based $A R$ as it is easier to use, more comfortable to develop, and is widely used in K-12 studies in the classroom setting (M. Ibáñez \& Delgado-kloos, 2018; Sırakaya \& Sirakaya, 2020). 
Table 2. AR Application Specification

\begin{tabular}{|c|c|c|c|c|}
\hline Type of AR & AR Display & Application Type & Subject (Topic) & Study \\
\hline \multirow{12}{*}{ Marker-based } & \multirow{8}{*}{ Handheld display } & Simulation-based game & Physic (Electrostatic) & Echeverría et al. (2012) \\
\hline & & Exhibition & Mathematic & Sommerauer and Müller (2014) \\
\hline & & \multirow[t]{2}{*}{ Problem-based simulator } & $\begin{array}{l}\text { Physic } \\
\text { (Electromagnetism) }\end{array}$ & Ibáñez et al. (2014) \\
\hline & & & Physic & Fidan and Tuncel (2019) \\
\hline & & Flipped learning AR simulator & $\begin{array}{l}\text { Science } \\
\text { (Electromagnetism) }\end{array}$ & Chang and Hwang (2018) \\
\hline & & Collaborative learning simulator & $\begin{array}{l}\text { Chemistry (Periodic } \\
\text { table) }\end{array}$ & Chen and Liu (2020) \\
\hline & & \multirow[b]{2}{*}{ Unspecified } & Physic & Akçayir et al. (2016) \\
\hline & & & Mathematic & $\begin{array}{l}\text { Ibáñez et al. (2020) } \\
\text { Conley et al. (2020) }\end{array}$ \\
\hline & HMD & Unspecified & Physic & Thees et al. (2020) \\
\hline & \multirow{3}{*}{$\begin{array}{l}\text { Desktop / laptop } \\
\text { display }\end{array}$} & Collaborative learning simulator & $\begin{array}{l}\text { Physic (Elastic } \\
\text { collision) }\end{array}$ & Lin et al. (2013) \\
\hline & & Inquiry-based simulator & Chemistry (Molecule) & Cai et al. (2014) \\
\hline & & Unspecified & Astronomy & Sahin and Yilmaz (2020) \\
\hline \multirow{3}{*}{ Location-based } & \multirow{3}{*}{ Handheld display } & Inquiry-based simulator & Natural science & $\begin{array}{l}\text { Kamarainen et al. (2013) } \\
\text { Chiang et al. (2014) } \\
\text { Georgiou and Kyza (2018) }\end{array}$ \\
\hline & & \multirow[b]{2}{*}{ Unspecified } & Astronomy & Zhang et al. (2014) \\
\hline & & & $\begin{array}{l}\text { Natural science } \\
\text { (Ecology) }\end{array}$ & Huang et al. (2016) \\
\hline
\end{tabular}


Most studies of both AR types commonly uses handhelds display such as tablet and smart phone since it provides better mobility compared to HMD or desktop / laptop display (Dey et al., 2018). Users can move around, whether indoor or in an outdoor setting, while handling handheld displays. However, although lack in mobility, the desktop/laptop displays in Cai et al. (2014) and Lin et al. (2013) suited the context of the study, which related to experimentation in a virtual laboratory.

Table 3. List of AR Developer

\begin{tabular}{ll}
\hline \multicolumn{1}{c}{ Study } & \multicolumn{1}{c}{ AR Developer } \\
\hline Kamarainen et al. (2013) & FreshAiR, Vuforia \\
Sommerauer and Müller (2014) & Aurasma \\
Ibáñez et al. (2014) & Unity, Vuforia \\
Cai et al. (2014) & Native app. (NyARToolkit, 3D modelling tool 3DS Max and \\
Chiang et al. (2014) & graphics engine Java 3D) \\
Akçayir et al. (2016) & Native app. (iOS) \\
Chang and Hwang (2018) & Metaio \\
Georgiou and Kyza (2018) & Unity \\
Fidan and Tuncel (2019) & TraceReaders \\
Conley et al. (2020) & Vuforia, Unity \\
Thees et al. (2020) & Vuforia, Unity \\
\hline
\end{tabular}

Regarding AR development tools, only 11 studies mention the development tools used, and the most frequent development tools based on Table 3 are Vuforia and Unity. Regarding types of digital elements used, ten studies mention elements used by the AR application. Most studies employ two types of digital elements (40\%), while only one study (10.0\%) employ one type of digital element in their intervention. Video and animation are the most frequent types of digital elements used in AR applications among the ten articles.

Table 4. Types of Digital Element Used

\begin{tabular}{|c|c|c|c|c|c|c|}
\hline Study & 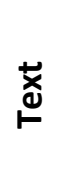 & 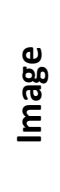 & $\begin{array}{l}\bar{\Phi} \\
\frac{0}{0} \\
\sum_{0} \\
0\end{array}$ & $\frac{\frac{0}{\frac{0}{0}}}{\frac{3}{\alpha}}$ & $\frac{\text { O }}{\frac{0}{2}}$ & 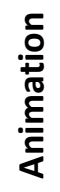 \\
\hline Kamarainen et al. (2013) & $\mathrm{v}$ & $\mathrm{v}$ & $\mathrm{v}$ & & $\mathrm{v}$ & $\sqrt{ }$ \\
\hline Lin et al. (2013) & v & v & V & & & v \\
\hline Sommerauer and Müller (2014) & & & & v & $\checkmark$ & v \\
\hline Akçayir et al. (2016) & & $\mathrm{v}$ & & & $\mathrm{v}$ & \\
\hline Chang and Hwang (2018) & & & & & $v$ & \\
\hline Georgiou and Kyza (2018) & & v & & & $v$ & \\
\hline Fidan and Tuncel (2019) & & & v & & & v \\
\hline Conley et al. (2020) & & & V & & & v \\
\hline Chen and Liu (2020) & & $\mathrm{v}$ & & $\mathrm{v}$ & & v \\
\hline Sahin and Yilmaz (2020) & $\mathrm{v}$ & & $\mathrm{v}$ & & $\mathrm{v}$ & \\
\hline
\end{tabular}

\subsection{AR Advantages in STEM}

The benefits of AR in STEM studies are categorised into four themes, such as its contribution to learners, the learning outcomes, the interaction of $A R$, and other advantages.

\subsubsection{Contribution to Learners}

The utilisation of AR technology benefits learners through increased achievement (Cai et al., 2014; Chen \& Liu, 2020; Echeverría et al., 2012; Fidan \& Tuncel, 2019) and learning performance (Chang \& 
Hwang, 2018; Georgiou \& Kyza, 2018; Zhang et al., 2014). AR assists knowledge construction (Chiang et al., 2014), and supports the learner to understand more of the topic learned (Chiu et al., 2015; Fidan \& Tuncel, 2019; Kamarainen et al., 2013). The virtual element enhances the learning experience and leads to the memorisation of procedural knowledge among students (Cai et al., 2014). This pattern of finding has been shown in previous work, where learning performance is commonly measured in research complementary to science fields (Lai \& Bower, 2019). However, the impact of AR in STEM education differed among learners and the context of their study. For instance, Georgiou and Kyza (2018) reported that secondary students' performance had significantly improved in a science field trip conducted with AR location-based approach. However, in Conley et al., (2020), learning statistic via "MantarayAR" benefit only students with low prior knowledge of the topic taught. Earlier research indicates that the mental imagery process varies among students (Palmiero et al., 2019). Students may improve their skills and achieve desired learning outcomes by spatial visualisation training and the use of proper tools such as in AR. Students will develop positive attitudes (Cai et al., 2014; Sahin \& Yilmaz, 2020), thus increasing their interest (Chen \& Liu, 2020) and motivation to learn (Chang \& Hwang, 2018; M. B. Ibáñez et al., 2014, 2020). AR facilitates learning by allowing students to conduct experiments efficiently and comfortably (Akçayir et al., 2016). Students also benefit from immediate feedback after using the technology to clarify concepts since it encourages further learning (T. C. Huang et al., 2016). Therefore, the implementation of AR increases learner satisfaction (Cai et al., 2014), and leads to positive emotions on the STEM subject area (T. C. Huang et al., 2016).

\subsubsection{Learning Outcomes}

According to the review, most articles mentioned visualisation as an essential learning outcome by implementing AR in STEM education. AR facilitates learners to visualise abstract concepts (Cai et al., 2014; Sahin \& Yilmaz, 2020). Students were able to visualise these abstract concepts (Chen \& Liu, 2020) in the form of visual information (Chiang et al., 2014; Safadel \& White, 2019), attain more significant learning, and subsequently, increases academic achievement. Learners also claimed that integrating AR in related studies are fun (Cai et al., 2014; Fidan \& Tuncel, 2019; Huang et al., 2016). Interaction between the AR application initiates learner interest, and learners gain more enjoyment from learning. However, the practice should be supported by a practical pedagogical approach to assist students throughout the learning period to avoid students being too engaged with their smartphones (Kamarainen et al., 2013).

Other than that, AR effectively increases learner's conceptual knowledge (Echeverría et al., 2012; Thees et al., 2020). Learners were able to deep understanding the theoretical concepts and retain the knowledge gain to resolve future problems arise in their STEM lessons (Lin et al., 2013). AR benefits students' learning outcomes by concretising abstract concepts (Fidan \& Tuncel, 2019), enhancing collaboration skills among classmates (Kamarainen et al., 2013), and increasing class engagement (Georgiou \& Kyza, 2018). While these results are promising, likely, AR can also support higher-order thinking skills as well as facilitate students for more in-depth learning instead of surface learning. Then again, previous reviews conducted by Garzón and Acevedo (2019) and Akçayır and Akçayır (2017) have already noted that the successful results shown might be possibly due to the novelty effect of the newly introduced technology to the students. Therefore, further studies are necessary to ascertain whether the novelty factor is going to continue to substantially affect the results of research conducted over more extended periods. 
Table 5. AR Contribution to Learners

\begin{tabular}{|c|c|c|c|c|c|c|c|c|c|c|c|c|c|c|c|c|}
\hline \multirow{2}{*}{$\begin{array}{c}\text { Sub-theme } \\
\text { Sub-theme code }\end{array}$} & \multicolumn{2}{|c|}{ IA } & \multicolumn{3}{|c|}{ IM } & \multicolumn{2}{|c|}{ PA } & \multicolumn{2}{|c|}{ II } & \multicolumn{2}{|c|}{ MLE } & \multicolumn{3}{|c|}{ IS } & \multicolumn{2}{|c|}{ PL } \\
\hline & LA & LP & UT & PK & KC & LE & LM & SM & SA & LA & I & $\mathbf{F}$ & IF & $\mathbf{S}$ & PE & RK \\
\hline Echeverría et al. (2012) & $\mathrm{V}$ & & & & & & & & & & & & & & & \\
\hline Kamarainen et al. (2013) & $\mathrm{V}$ & & $\mathrm{V}$ & & & & & $\mathrm{V}$ & & & & & & & & \\
\hline Lin et al. (2013) & $\mathrm{V}$ & & $\mathrm{V}$ & & & & & & & & & & & & & \\
\hline Sommerauer and Müller (2014) & & $\mathrm{V}$ & & & & & & & & & & & & & & $\mathrm{V}$ \\
\hline Ibáñez et al. (2014) & & $\mathrm{V}$ & $\mathrm{V}$ & & & & & $\mathrm{V}$ & & & & & & & $\mathrm{V}$ & \\
\hline Cai et al. (2014) & $\mathrm{V}$ & & & $\mathrm{V}$ & & & & $\mathrm{V}$ & & $\mathrm{V}$ & & & & $\mathrm{V}$ & & \\
\hline Chiang et al. (2014) & & & & & $\mathrm{V}$ & & & & & & & & & & & \\
\hline Zhang et al. (2014) & & $\mathrm{v}$ & & & & & & & & & $\mathrm{V}$ & & & & & $\mathrm{V}$ \\
\hline Chiu et al. (2015) & & & $\mathrm{V}$ & & & & & & & & & & & & & \\
\hline Huang et al. (2016) & & $\mathrm{v}$ & & & & $\mathrm{v}$ & & & & & & & $\mathrm{v}$ & & $\mathrm{v}$ & \\
\hline Akçayir et al. (2016) & & & $\mathrm{v}$ & & & & & & $\mathrm{v}$ & & & $\mathrm{v}$ & & & & \\
\hline Chang and Hwang (2018) & & $\mathrm{V}$ & & & & & $\mathrm{V}$ & & & & & & & & & \\
\hline Georgiou and Kyza (2018) & & v & & & & & & & & & & & & & & \\
\hline Fidan and Tuncel (2019) & $\mathrm{v}$ & & $\mathrm{v}$ & & & & & & $\mathrm{v}$ & & & & & & & $\mathrm{v}$ \\
\hline Sahin and Yilmaz (2020) & v & & & & & & & & v & & & & & & & \\
\hline Ibáñez et al. (2020) & v & & & & & & & $\mathrm{v}$ & & & & & & & & \\
\hline Chen and Liu (2020) & $v$ & & & & & & & & & & $\mathrm{~V}$ & & & & & v \\
\hline
\end{tabular}


Table 6. Learning Outcomes

\begin{tabular}{|c|c|c|c|c|c|c|}
\hline Sub-theme & CE & $\mathbf{V}$ & $\mathbf{F}$ & CL & $A C$ & CK \\
\hline Sub-theme code & E & SC & FL & CS & SC & CK \\
\hline Echeverría et al. (2012) & & & & & & 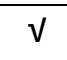 \\
\hline Kamarainen et al. (2013) & v & & & $v$ & & v \\
\hline Lin et al. (2013) & & & & & & $v$ \\
\hline Ibáñez et al. (2014) & & v & & & & \\
\hline Cai et al. (2014) & & v & $v$ & & & \\
\hline Chiang et al. (2014) & & v & & & & \\
\hline Huang et al. (2016) & & & v & & & \\
\hline Chang and Hwang (2018) & & & $v$ & & & \\
\hline Georgiou and Kyza (2018) & v & & & & & v \\
\hline Fidan and Tuncel (2019) & & & $\sqrt{ }$ & & $v$ & \\
\hline Sahin and Yilmaz (2020) & & v & & & & \\
\hline Thees et al. (2020) & & & & & & v \\
\hline Chen and Liu (2020) & & $v$ & & & & \\
\hline
\end{tabular}

Sub-theme: Increases class engagement (CE), Visualization (V), Fun learning (F), Collaborative learning (CL), Concretizes abstract concepts (AC), Increase conceptual knowledge (CK); Sub-theme codes: Engagement (E), Unobservable scientific concepts (SC), Fun learning (FL), Collaboration skills (CK), Scientific concepts (SC), Conceptual knowledge (CK)

\subsubsection{Interaction}

AR enhances the interaction between learners, teachers, and the environment. The adopted technology promotes students' interaction with their environment as well as their classmates (Kamarainen et al., 2013). Students are more engaged in communication with the teacher (Zhang et al., 2014) since the teacher has more time to explain and interact with students compared to the traditional classroom, which is based on memorisation (Chang \& Hwang, 2018). AR enables studentcentred learning (Kamarainen et al., 2013). Students freely explore knowledge regarding the topic (Chiang et al., 2014) as AR provides personalised guidance for students centred-learning (Chang \& Hwang, 2018). Students can finish their experiments on time with less help from the laboratory instructor compared to conducting regular experiments (Akçayir et al., 2016).

\subsubsection{Other Advantages}

Another advantage of implementing AR in the STEM classroom is that it is easy to use for students. Students had little difficulty in handling the AR application (Chiu et al., 2015), and could operate AR software within a short timeframe (Cai et al., 2014).

Table 7. Interaction and Other Advantages

\begin{tabular}{|c|c|c|c|c|}
\hline Sub-theme & SCL & & & Others \\
\hline Sub-theme code & SCL & S-E & S-T & $\mathbf{E}$ \\
\hline Kamarainen et al. (2013) & $\sqrt{ }$ & $\mathrm{V}$ & & \\
\hline Cai et al. (2014) & & & & $\mathrm{v}$ \\
\hline Chiang et al. (2014) & $\mathrm{v}$ & & & \\
\hline Zhang et al. (2014) & & & $\sqrt{ }$ & \\
\hline Chiu et al. (2015) & & & & 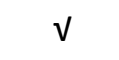 \\
\hline Akçayir et al. (2016) & $\sqrt{ }$ & & & \\
\hline Chang and Hwang (2018) & $\mathrm{v}$ & & $\mathrm{v}$ & \\
\hline
\end{tabular}

Sub-theme: Student-centred learning (SCL), Increase student interaction (SI), Easy to use (E); Sub-theme codes: Studentcentred learning (SCL), interaction among student and environment (S-E), interaction among student and teacher (S-T); Easy to use for students (E) 


\subsection{Challenges in Implementing AR in STEM Education}

While articles associated with AR in STEM education emphasised the advantages of its application, there are several obstacles encountered in implementing the technology. The most common identified challenge was the problem in detecting the marker. Students viewed the stability of the AR tool as unsatisfactory (Cai et al., 2014) since the marker was sometimes left undetected (Fidan \& Tuncel, 2019; Ibáñez et al., 2014). Excessive or insufficient lighting in the classroom setting may be the cause of this problem (Cai et al., 2014; Chang \& Hwang, 2018; Sahin \& Yilmaz, 2020). Therefore, Gün and Atasoy (2017) suggest controlling the amount of light in the classroom environment to enable markers to be detected easily. The usability of the device used is also a challenge in implementing AR in STEM education. It requires a more extensive setup such as rearranging furniture to provide enough space for students to move around, locating markers in selected locations, and also monitoring the lighting from time to time (Echeverría et al., 2012). Apart from that, users claimed that the tablets used are heavy to carry around in a study conducted in a museum environment (Sommerauer \& Müller, 2014). Users also argued that the use of devices for a more extended period could lead to uncomfortable health conditions such as backache (Fidan \& Tuncel, 2019) and getting tired of holding the tablet computer to marker cards for long periods at a time (M. B. Ibáñez et al., 2014).

In terms of AR features, students suggested the need to add realistic animation elements to the application (Cai et al., 2014). Gün and Atasoy (2017) proposed the inclusion of animation in AR applications to enhance student's interest in the medium. Also, animated visualisation benefit students in term of learning outcomes (Nurdyansyah, Mandarani, \& Rais, 2020; Sugiharti, Dalimunthe, \& Syuhada, 2020) as the animation facilitate students in memorising and understanding of knowledge (Berney \& Bétrancourt, 2016; Günbaş, 2020). Through animation, factual and conceptual knowledge can be conveyed simply that both children and adult can easily understand.

Other challenges include technical glitches while operating AR applications (Fidan \& Tuncel, 2019; Kamarainen et al., 2013; Sahin \& Yilmaz, 2020) and the high cost of the devices (Echeverría et al., 2012). However, the technological developments of portable gadgets and lower prices of these devices may reduce these threats in the upcoming years (Sırakaya \& Sirakaya, 2020).

Table 8. Challenges of AR in STEM Education

\begin{tabular}{|c|c|c|c|}
\hline Sub-themes & Sub-themes codes & f & Sample research \\
\hline \multirow{3}{*}{$\begin{array}{l}\text { Marker detection } \\
\text { problem }\end{array}$} & Insufficient lighting & 3 & Chang and Hwang (2018) \\
\hline & Marker not recognized & 2 & Ibáñez et al. (2014) \\
\hline & Stability & 1 & Cai et al. (2014) \\
\hline Technical problems & Technical glitches & 3 & Kamarainen et al. (2013) \\
\hline \multirow{3}{*}{ Usability of device } & Heavy & 1 & $\begin{array}{l}\text { Sommerauer and Müller } \\
\text { (2014) }\end{array}$ \\
\hline & $\begin{array}{l}\text { Uncomfortable if used for a } \\
\text { long time }\end{array}$ & 1 & Fidan and Tuncel (2019) \\
\hline & Complexity & 1 & Echeverría et al. (2012) \\
\hline Cost & Expensive & 1 & Echeverría et al. (2012) \\
\hline \multirow{2}{*}{ Features of AR } & Not realistic & 1 & Cai et al. (2014) \\
\hline & Less animation element & 1 & Cai et al. (2014) \\
\hline
\end{tabular}


Figure 6. Overall Themes and Sub-themes of AR Benefit to STEM Education

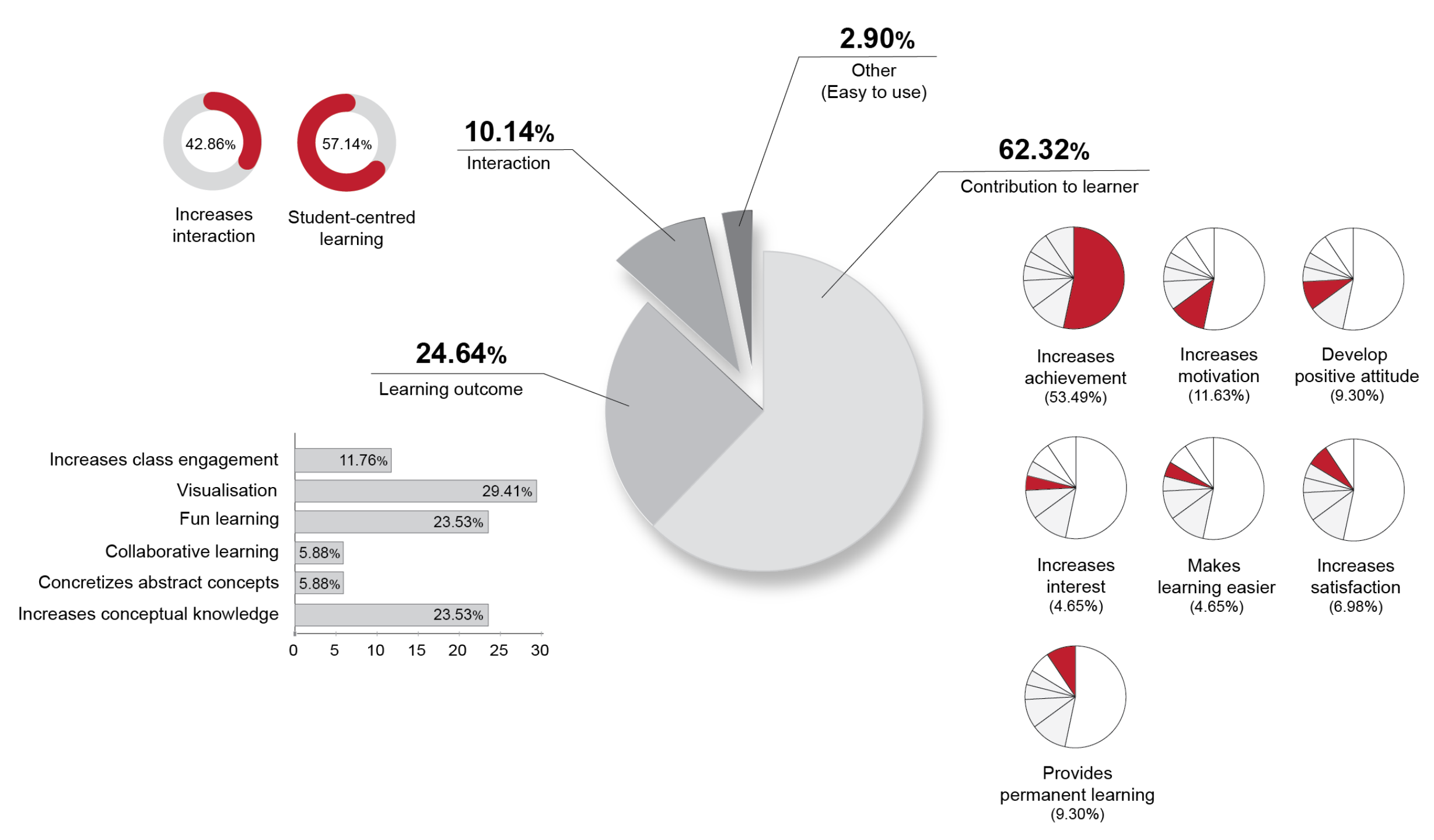




\section{Conclusion}

This study presents a systematic review of the present research in AR as a developing technology for assisting STEM education learning. The review shows that the first empirical articles on AR in STEM education were published in 2012, and the integration of technology in education has been continually explored until recently and is expected to further studies in various aspects for betterment in the coming years. Other findings from this study can assist the upcoming AR integration in STEM studies. Preferred sample groups in previous studies were secondary school students. Since secondary school students are ideal sample groups based on the review in AR and STEM studies, the potential of AR could be further extended apart from only focusing on student's performance and learning outcomes. Most studies applied the quantitative method with a preferred sample size between 101 and 200, while the favourable data collection methods are achievement tests and surveys or questionnaires. The studies were conducted in STEM subject-based learning environments, which focus mainly on science and mathematics. Further research can include studies within the element of technology and engineering in a STEM context.

The first research question aimed to uncover the general characteristics of AR technology implemented in STEM studies. Two categories of application types of AR use in STEM studies are discovered in the literature, which is AR as an inquiry-based simulator and problem-based simulator. Other than that, it is also reported that marker-based $A R$ is frequently used compared to locationbased AR in this review. However, the literature reviewed shows that marker-based AR is commonly used in Mathematics and Physic studies as a problem-based simulator and commonly conducted in class and virtual laboratory. The location-based AR, on the other hand commonly used in Natural Science inquiry-based learning, conducted mostly at the out-of-school context. Regarding AR display, a handheld display is preferred compared to HMD and desktop/laptop due to its mobility and ease of use. The most frequent development tools used in this study are Vuforia and Unity, while nearly half of the related studies employ two types of digital elements. Video and animation are the most frequently mentioned types of digital elements used in AR applications to enhance the learning experience. It would be interesting to explore more types of digital elements that can be used in AR development that can stimulate other senses apart from sight.

The second research question refers to the benefits of AR use in STEM education. The most stated benefit of $A R$ is that it stimulates learning achievement, assists in visualisation, and promotes studentcentred learning. However, the AR impact on learners might be contributed by the novelty of the innovation. Measures such as piloting before the actual application and delaying the implementation phase are recommended to ease the novelty effect. Although the overall result is encouraging, the results in individual studies may be dependent on various factors such as learner type, subject, learning environment or methodology, length of intervention conducted, and student's computer attitude. Hence, these advantages of AR implementation in STEM education signify that under certain circumstances, AR has a positive influence on learning achievement and visualisation. Therefore, further study should consider the impact of AR use on different individual characteristics (e.g., level of performance, motivation, spatial ability) as it will produce remarkable outcomes.

The third research question on challenges encountered while integrating AR in STEM studies was generally associated with problems of marker detection and the usability of the devices. However, technical issues identified with the detection of the markers may be overcome in the coming years with technological advancement. This current review is centred on the characteristics, gains, and difficulties of AR in the field of STEM education. Further research can be conducted through a pedagogical approach and the potential of AR applications to support students' higher-order thinking skills in STEM education studies.

\section{Limitations of the study}

The articles studied in this research are limited to the journals indexed in the ScienceDirect database. However, other databases such as SCCI, ERIC, ProQuest, and Springer may also be used in 
future research. This research is also limited to studies presented in article format. Future researchers may include the examination of a wider variety of documents such as conference papers, editorials, theses, and dissertations, as it may lead to the discovery of many more advantages and obstacles regarding educational uses of AR technology in STEM education.

\section{Acknowledgement}

The authors gratefully acknowledge support from the Malaysia Ministry of Education under HLP Programme.

\section{References}

1. Akçayir, M., Akçayir, G., Pektaş, H. M., \& Ocak, M. A. (2016). Augmented reality in science laboratories: The effects of augmented reality on university students' laboratory skills and attitudes toward science laboratories. Computers in Human Behavior, 57, 334-342.

2. Akçayır, M., \& Akçayır, G. (2017). Advantages and challenges associated with augmented reality for education: A systematic review of the literature. Educational Research Review, 20, 1-11.

3. Ali, R., \& Bakar, A. (2019). The probability to memorize and understand textbook information: Socioeconomic class as the predictor for cognitive processing strategies in Pakistani education system. Pakistan Journal of Social Sciences (PJSS), 39(1), 253-270.

4. Altinpulluk, H. (2019). Determining the trends of using augmented reality in education between 2006-2016. Education and Information Technologies, 24(2), 1089-1114.

5. Askari, E., Brandon, D., Galvin, S., \& Greenhow, C. (2018). Youth, learning and social media in K-12 education: The state of the field. Proceedings of International Conference of the Learning Sciences, ICLS, 1, 344-351.

6. Bacca, J., Baldiris, S., Fabregat, R., Graf, S., \& Kinshuk. (2014). Augmented reality trends in education: A systematic review of research and applications. Educational Technology and Society, 17(4), 133-149.

7. Berney, S., \& Bétrancourt, M. (2016). Does animation enhance learning? A meta-analysis. Computers and Education, 101, 150-167.

8. Brown, M., Mccormack, M., Reeves, J., Brooks, D. C., Grajek, S., Alexander, B., ... Weber, N. (2020). 2020 EDUCAUSE Horizon report ${ }^{\mathrm{TM}}$ : Teaching and learning edition. Louisville: Educause Publication.

9. Cai, S., Chiang, F., Sun, Y., Lin, C., \& Lee, J. J. (2017). Applications of augmented reality-based natural interactive learning in magnetic field instruction. Interactive Learning Environments, 25(6), 778791.

10.Cai, S., Wang, X., \& Chiang, F. K. (2014). A case study of augmented reality simulation system application in a chemistry course. Computers in Human Behavior, 37, 31-40.

11.Chang, S. C., \& Hwang, G. J. (2018). Impacts of an augmented reality-based flipped learning guiding approach on students' scientific project performance and perceptions. Computers and Education, 125, 226-239.

12.Chen, S.-Y., \& Liu, S. (2020). Using augmented reality to experiment with elements in a chemistry course. Computers in Human Behavior, 111, 106418.

13.Cheng, Y., Yen, C., Su, N., Ting, T., Yueh, W., \& Huang, M. (2019). Enhancing students' botanical learning by using augmented reality. Universal Access in the Information Society, 18(2), 231-241.

14.Chiang, T. H. C. C., Yang, S. J. H. H., \& Hwang, G. J. (2014). Students' online interactive patterns in augmented reality-based inquiry activities. Computers and Education, 78, 97-108.

15.Chiu, J. L., Dejaegher, C. J., \& Chao, J. (2015). The effects of augmented virtual science laboratories on middle school students' understanding of gas properties. Computers and Education, 85, 59-73.

16.Conley, Q., Atkinson, R. K., Nguyen, F., \& Nelson, B. C. (2020). MantarayAR: Leveraging augmented reality to teach probability and sampling. Computers and Education, 153, 103895.

17.Dey, A., Billinghurst, M., Lindeman, R. W., \& Swan, J. E. (2018). A systematic review of 10 years of augmented reality usability studies: 2005 to 2014. In Frontiers in Robotics and Al (Vol. 5). 
18.Diegmann, P., Schmidt-Kraepelin, M., Van den Eynden, S., \& Basten, D. (2015). Benefits of augmented reality in aducational environments-A systematic literature review. In 12th International Conference on Wirtschaftsinformatik (pp. 1542-1556).

19.Echeverría, A., Améstica, M., Gil, F., Nussbaum, M., Barrios, E., \& Leclerc, S. (2012). Exploring different technological platforms for supporting co-located collaborative games in the classroom. Computers in Human Behavior, 28(4), 1170-1177.

20.Erbas, C., \& Demirer, V. (2019). The effects of augmented reality on students' academic achievement and motivation in a biology course. Journal of Computer Assisted Learning, 35(3), 450-458.

21.Fidan, M., \& Tuncel, M. (2019). Integrating augmented reality into problem based learning: The effects on learning achievement and attitude in physics education. Computers and Education, 142(2019), 103635.

22.Garzón, J., \& Acevedo, J. (2019). Meta-analysis of the impact of augmented reality on students' learning gains. Educational Research Review, 27, 244-260.

23.Georgiou, Y., \& Kyza, E. A. (2018). Relations between student motivation, immersion and learning outcomes in location-based augmented reality settings. Computers in Human Behavior, 89, 173181.

24.Ghazi, S. R., Ullah, K., \& Jan, F. A. (2016). Concrete operational stage of Piaget's Cognitive Development Theory: An implication in learning mathematics. Gomal University Journal of Research, 32(1), 9-20.

25.Gies, T. (2018). The ScienceDirect accessibility journey: A case study. Learned Publishing, 31(1), 6976.

26.Gough, D., Oliver, S., \& Thomas, J. (2012). An introduction to systemic reviews.

27.Gün, E. T., \& Atasoy, B. (2017). The effects of augmented reality on elementary school students' spatial ability and academic achievement. Egitim ve Bilim, 42(191), 31-51.

28.Günbaş, N. (2020). Students solve mathematics word problems in animated cartoons. Malaysian Online Journal of Educational Technology, 8(2), 43-57.

29.Gusenbauer, M., \& Haddaway, N. R. (2020). Which academic search systems are suitable for systematic reviews or meta-analyses? Evaluating retrieval qualities of Google Scholar, PubMed, and 26 other resources. Research Syntesis Methods, 11(2), 181-217.

30. Hayes, J. C., \& Kraemer, D. J. M. (2017). Grounded understanding of abstract concepts: The case of STEM learning. Cognitive Research: Principles and Implications, 2(7).

31.Huang, T.-C., \& Lin, C.-Y. (2016). From 3D modeling to 3D printing: Development of a differentiated spatial ability teaching model. Telematics and Informatics.

32.Huang, T. C., Chen, C. C., \& Chou, Y. W. (2016). Animating eco-education: To see, feel, and discover in an augmented reality-based experiential learning environment. Computers and Education, 96, 72-82.

33.Ibáñez, M. B., Di Serio, Á., Villarán, D., \& Delgado Kloos, C. (2014). Experimenting with electromagnetism using augmented reality: Impact on flow student experience and educational effectiveness. Computers and Education, 71, 1-13.

34.Ibáñez, M., \& Delgado-Kloos, C. (2018). Augmented reality for STEM learning: A systematic review. Computers and Education, 123, 109-123.

35.Ibáñeza, M. B., Portillo, A. U., Cabada, R. Z., \& Barrón, M. L. (2020). Impact of augmented reality technology on academic achievement and motivation of students from public and private Mexican schools. A case study in a middle-school geometry course. Computers and Education, 145, 103734.

36.Kamarainen, A. M., Metcalf, S., Grotzer, T., Browne, A., Mazzuca, D., Tutwiler, M. S., \& Dede, C. (2013). ECoMOBILE: Integrating augmented reality and probeware with environmental education field trips. Computers and Education, 68, 545-556.

37.Khan, T., Johnston, K., \& Ophoff, J. (2019). The impact of an augmented reality application on learning motivation of students. Advances in Human-Computer Interaction.

38. Kohler, R. (2014). Jean Piaget. Bloomsbury Academic. 
39.Korucu, A. T., Usta, E., \& Yavuzaslan, i. F. (2016). The use of augmented reality technology in education: Content analysis of the research period 2007-2016 in Turkey. Journal of Field Education Research, 2(2), 84-95.

40.Lai, J. W. M., \& Bower, M. (2019). How is the use of technology in education evaluated? A systematic review. Computers and Education, 133, 27-42.

41.Laine, T. H., Nygren, E., Dirin, A., \& Suk, H. J. (2016). Science Spots AR: A platform for science learning games with augmented reality. Educational Technology Research and Development, 64(3), 507-531.

42.Lin, T. J., Duh, H. B. L., Li, N., Wang, H. Y., \& Tsai, C. C. (2013). An investigation of learners' collaborative knowledge construction performances and behavior patterns in an augmented reality simulation system. Computers and Education, 68, 314-321.

43.Malhi, R. S. (2019). Creating high-performing schools. Retrieved from https://www.malaysiakini.com/news/501068

44.Milton, J. H., Flores, M. M., Moore, A. J., Taylor, J. L. J., \& Burton, M. E. (2018). Using the concreterepresentational-abstract sequence to teach conceptual understanding of basic multiplication and division. Learning Disability Quarterly, 42(1), 32-45.

45.Moher, D., Liberati, A., Tetzlaff, J., Altman, D. G., \& Group, T. P. (2009). Preferred reporting items for systematic reviews and meta-analyses: The PRISMA statement. PLoS Medicine, 6(7), e1000097.

46. Moorhouse, N., Dieck, M. C., \& Jung, T. (2019). An experiential view to children learning in museums with augmented reality. Museum Management and Curatorship, 34(4), 402-418.

47.Nurdyansyah, N., Mandarani, V., \& Rais, P. (2020). How to make use of animation to improve primary school students' english achievement? JEES (Journal of English Educators Society), 5(1), 53-59.

48.Palmiero, M., Piccardi, L., Giancola, M., Nori, R., D’Amico, S., \& Olivetti Belardinelli, M. (2019). The format of mental imagery: from a critical review to an integrated embodied representation approach. Cognitive Processing, 20(3), 277-289.

49.Pellas, N., Fotaris, P., Kazanidis, I., \& Wells, D. (2019). Augmenting the learning experience in primary and secondary school education: A systematic review of recent trends in augmented reality game-based learning. Virtual Reality, 23(4), 329-346.

50.Petri, G., \& Wangenheim, C. G. von. (2017). How games for computing education are evaluated? A systematic literature review. Computers and Education, 107, 68-90.

51.Pirttimaa, M., Husu, J., Metsa, M., Metsärinne, M., \& Metsa, M. (2017). Uncovering procedural knowledge in craft, design, and technology education: A case of hands-on activities in electronics. International Journal of Technology and Design Education, 27(2), 215-231.

52.Safadel, P., \& White, D. (2019). Facilitating molecular biology teaching by using Augmented Reality (AR) and Protein Data Bank (PDB). TechTrends, 63(2), 188-193.

53.Sahin, D., \& Yilmaz, R. M. (2020). The effect of augmented reality technology on middle school students' achievements and attitudes towards science education. Computers and Education, 144, 103710.

54.Saltan, F., \& Arslan, Ö. (2017). The use of augmented reality in formal education: A scoping review. Eurasia Journal of Mathematics, Science and Technology Education, 13(2), 503-520.

55.Sharma, K., Torrado, J. C., Gómez, J., \& Jaccheri, L. (2021). Improving girls' perception of computer science as a viable career option through game playing and design: Lessons from a systematic literature review. Entertainment Computing, 36(October 2019).

56.Shiner, N. (2018). Is there a role for simulation based education within conventional diagnostic radiography? A literature review. Radiography, 24(3), 262-271.

57.Silva, M. M. O. da, Teixeira, J. M. X. N., Cavalcante, P. S., \& Teichrieb, V. (2019). Perspectives on how to evaluate augmented reality technology tools for education: A systematic review. Journal of the Brazilian Computer Society, 25(3), 1-18.

58.Sirakaya, M., \& Sirakaya, D. A. (2018). Trends in educational augmented reality studies: A systematic review. Malaysian Online Journal of Educational Technology, 6(2), 60-74. 
59.Sırakaya, M., \& Alsancak Sırakaya, D. (2020). Augmented reality in STEM education: A systematic review. Interactive Learning Environments, 1-14.

60.Sommerauer, P., \& Müller, O. (2014). Augmented reality in informal learning environments: A field experiment in a mathematics exhibition. Computers and Education, 79, 59-68.

61.Sommerauer, P., \& Müller, O. (2018). Augmented reality for teaching and learning-A literature review on theoretical and empirical foundations. In 26th European Conference on Information Systems: Beyond Digitization - Facets of Socio-Technical Change, ECIS 2018.

62.Sugiharti, G., Dalimunthe, M., \& Syuhada, F. A. (2020). Learning media animations for subjects evaluation and Chemistry learning outcomes. Journal of Physics: Conference Series, 1462(1), 012021.

63.Thees, M., Kapp, S., Strzys, M. P., Beil, F., Lukowicz, P., \& Kuhn, J. (2020). Effects of augmented reality on learning and cognitive load in university physics laboratory courses. Computers in Human Behavior, 108, 106316.

64. Thibaut, L., Ceuppens, S., De Loof, H., De Meester, J., Goovaerts, L., Struyf, A., ... Depaepe, F. (2018). Integrated STEM education: A systematic review of instructional practices in secondary education. European Journal of STEM Education, 3(1), 1-12.

65.Tikito, l., \& Souissi, N. (2019). Meta-analysis of systematic literature review methods. International Journal of Modern Education and Computer Science, 11(2), 17-25.

66. Umi Fairus Mohd Jamil, \& Fazlinda Ab Halim. (2018). Kaedah mnemonik akronim dalam mata pelajaran Reka Bentuk dan Teknologi di Sekolah Rendah Agama Bersepadu Mersing. Online Journal for TVET Practioners, 3(1).

67.Wan Jaafar, W. N., \& Maat, S. M. (2020). The relationship between self efficacy and motivation with STEM education: A systematic literature review. International Journal of Modern Education, 2(4), 19-29.

68.Wang, L., Lee, H., \& Ju, D. Y. (2019). Impact of digital content on young children's reading interest and concentration for books. Behaviour and Information Technology, 38(1), 1-8.

69.Wilhelmsen, T., \& Sørensen, M. (2017). Inclusion of children with disabilities in physical education: A systematic review of literature from 2009 to 2015. Adapted Physical Activity Quarterly, 34(3), 311-337.

70.Xiao, Y., \& Watson, M. (2019). Guidance on conducting a systematic literature review. Journal of Planning Education and Research, 39(1), 93-112.

71.Yu, S.-J., Sun, J. C.-Y., \& Chen, O. T.-C. (2019). Effect of AR-based online wearable guides on university students' situational interest and learning performance. Universal Access in the Information Society, 18(2), 287-299.

72.Zhang, J., Sung, Y. T., Hou, H. T., \& Chang, K. E. (2014). The development and evaluation of an augmented reality-based armillary sphere for astronomical observation instruction. Computers and Education, 73, 178-188. 


\section{APPENDIX}

\section{List of AR Application}

\begin{tabular}{|c|c|c|c|c|}
\hline Reference & Topic & Name & Application type & Scenario \\
\hline $\begin{array}{l}\text { Echeverría et al. } \\
\text { (2012) }\end{array}$ & $\begin{array}{l}\text { Physic } \\
\text { (Electrostatic) }\end{array}$ & First Colony & $\begin{array}{l}\text { Game-based } \\
\text { simulator }\end{array}$ & $\begin{array}{l}\text { Students play the role of an astronaut from the first human } \\
\text { colony on an extra-solar planet. The astronaut was given a } \\
\text { mission to bring back a precious electrically charged crystal } \\
\text { from space to gather energy for their colony. The player } \\
\text { moves the crystal in different direction and acceleration and } \\
\text { avoiding obstacles through manipulating the value of } \\
\text { electrical charged (Coulomb's law). }\end{array}$ \\
\hline $\begin{array}{l}\text { Kamarainen et al. } \\
(2013)\end{array}$ & Natural science & EcoMobile & $\begin{array}{l}\text { Inquiry-based } \\
\text { simulator }\end{array}$ & $\begin{array}{l}\text { Students explore a pond to determine the types of causal } \\
\text { dynamics it exhibits }\end{array}$ \\
\hline Lin et al. (2013) & $\begin{array}{l}\text { Physic } \\
\text { (Elastic collision) }\end{array}$ & AR Physics & $\begin{array}{l}\text { Collaborative } \\
\text { learning simulator }\end{array}$ & $\begin{array}{l}\text { The student in each dyad visualised two 3D virtual cubes on } \\
\text { a marker. Student manipulated the mass and the initial } \\
\text { velocity of the cube to simulate elastic collision. Numerical } \\
\text { data of mass, velocity, momentum, and kinetic energy of the } \\
\text { two objects are displayed on the screen. }\end{array}$ \\
\hline $\begin{array}{l}\text { Sommerauer and } \\
\text { Müller (2014) }\end{array}$ & Mathematic & Unspecified & Exhibition & $\begin{array}{l}\text { Students are divided into two groups and visit an exhibition. } \\
\text { The exhibition consists of } 275 \text { exhibits divided into four } \\
\text { rooms, and only twelve exhibits are augmented. }\end{array}$ \\
\hline $\begin{array}{l}\text { Ibáñez et al. } \\
\text { (2014) }\end{array}$ & $\begin{array}{l}\text { Physic } \\
\text { (Electromagnetism) }\end{array}$ & Unspecified & $\begin{array}{l}\text { Problem-based } \\
\text { simulation }\end{array}$ & $\begin{array}{l}\text { The learning activity involves exploring the effect of a } \\
\text { magnetic field on a circuit and Lorentz's law by constructing } \\
\text { a circuit to solve the proposed problem. Students are } \\
\text { required to add a new element to the circuit constructed in } \\
\text { each stage and can read about the concept involved. }\end{array}$ \\
\hline Cai et al. (2014) & $\begin{array}{l}\text { Chemistry } \\
\text { (Molecule) }\end{array}$ & Unspecified & $\begin{array}{l}\text { Inquiry-based } \\
\text { simulation }\end{array}$ & $\begin{array}{l}\text { Students use markers to represent particles and construct } \\
\text { molecules and substances in a virtual laboratory. Students } \\
\text { explore and conclude their inquiry-based learning and are } \\
\text { given instruction needed. }\end{array}$ \\
\hline $\begin{array}{l}\text { Chiang et al. } \\
(2014)\end{array}$ & $\begin{array}{l}\text { Natural science } \\
\text { (Ecology) }\end{array}$ & Unspecified & $\begin{array}{l}\text { Inquiry-based } \\
\text { simulator }\end{array}$ & $\begin{array}{l}\text { The students used the location-based AR to browse the } \\
\text { knowledge and information about aquatic plants. Students }\end{array}$ \\
\hline
\end{tabular}




\begin{tabular}{|c|c|c|c|c|}
\hline & & & & $\begin{array}{l}\text { also recorded knowledge and information gain along the } \\
\text { field trip. }\end{array}$ \\
\hline $\begin{array}{l}\text { Zhang et al. } \\
(2014)\end{array}$ & Astronomy & MDAS & $\begin{array}{l}\text { Inquiry-based } \\
\text { simulator }\end{array}$ & $\begin{array}{l}\text { Students involved in night time stargazing activities and are } \\
\text { given outdoor instruction }\end{array}$ \\
\hline Chiu et al. (2015) & $\begin{array}{l}\text { Science } \\
\text { (Gas properties) }\end{array}$ & Frame lab & $\begin{array}{l}\text { Inquiry-based } \\
\text { simulator }\end{array}$ & $\begin{array}{l}\text { Students worked through a series of five activities to } \\
\text { discover scientific phenomena and to interpret data } \\
\text { gathered from the Frame lab. Students observe molecules } \\
\text { simulation and adjusting the heat by placing the hot and cold } \\
\text { jars near the Frame. }\end{array}$ \\
\hline $\begin{array}{l}\text { Huang et al. } \\
(2016)\end{array}$ & $\begin{array}{l}\text { Natural science } \\
\text { (Ecology) }\end{array}$ & $\begin{array}{l}\text { eco-discovery AR- } \\
\text { based learning } \\
\text { system (EDALM) }\end{array}$ & $\begin{array}{l}\text { Collaborative } \\
\text { inquiry-based } \\
\text { simulator }\end{array}$ & $\begin{array}{l}\text { Students toured a museum garden to learn the ecology of } \\
\text { plants. Students use EDALM to observe an interactive virtual } \\
\text { plant silhouette while guiding them to experience and } \\
\text { explore the surrounding environment. }\end{array}$ \\
\hline $\begin{array}{l}\text { Akçayir et al. } \\
(2016)\end{array}$ & Physic & Unspecified & $\begin{array}{l}\text { Inquiry-based } \\
\text { simulator }\end{array}$ & $\begin{array}{l}\text { Students conducted their experiments using their AR- } \\
\text { assisted laboratory manuals }\end{array}$ \\
\hline $\begin{array}{l}\text { Chang and } \\
\text { Hwang (2018) }\end{array}$ & $\begin{array}{l}\text { Science } \\
\text { Electromagnetism }\end{array}$ & $\begin{array}{l}\text { AR-based flipped } \\
\text { learning system }\end{array}$ & $\begin{array}{l}\text { flipped learning AR } \\
\text { simulator }\end{array}$ & $\begin{array}{l}\text { The students complete an electromagnet project before the } \\
\text { learning activity. They watch the pre-class videos and finish } \\
\text { the worksheets at home with AR operating guidance system. }\end{array}$ \\
\hline $\begin{array}{l}\text { Georgiou and } \\
\text { Kyza (2018) }\end{array}$ & Natural science & $\begin{array}{l}\text { Mystery at the } \\
\text { Lake }\end{array}$ & $\begin{array}{l}\text { Inquiry-based } \\
\text { simulator }\end{array}$ & $\begin{array}{l}\text { Students assumed the role of environmental investigators } \\
\text { and are investigating the mysterious decline of the lake's } \\
\text { mallard ducks. }\end{array}$ \\
\hline $\begin{array}{l}\text { Fidan and Tuncel } \\
\text { (2019) }\end{array}$ & Physic & FenAR & $\begin{array}{l}\text { Problem-based } \\
\text { simulator }\end{array}$ & $\begin{array}{l}\text { FenAR apps present problem scenarios. Based on the } \\
\text { scenarios, the students learned the physics concept through } \\
\text { a problem-based learning process. }\end{array}$ \\
\hline $\begin{array}{l}\text { Sahin and Yilmaz } \\
(2020)\end{array}$ & Astronomy & AR-based booklet & $\begin{array}{l}\text { Inquiry-based } \\
\text { simulator }\end{array}$ & The subject was taught via the AR-based activity booklet \\
\hline $\begin{array}{l}\text { Ibáñez et al. } \\
(2020)\end{array}$ & $\begin{array}{l}\text { Mathematic } \\
\text { Geometry }\end{array}$ & ARGeo & $\begin{array}{l}\text { Inquiry-based } \\
\text { simulator }\end{array}$ & $\begin{array}{l}\text { Student answer question related to geometric bodies in } \\
\text { ARGeo }\end{array}$ \\
\hline $\begin{array}{l}\text { Conley et al. } \\
(2020)\end{array}$ & $\begin{array}{l}\text { Mathematic } \\
\text { Probability }\end{array}$ & MantarayAR & $\begin{array}{l}\text { Problem-based } \\
\text { simulator }\end{array}$ & $\begin{array}{l}\text { Students play a role as an environmental scientist and need } \\
\text { to investigate a recent oil spill that happened near a small } \\
\text { bay side town in Alaska. Students were briefed on the } \\
\text { behaviour and treatment plan for the different types of oil, } \\
\text { the participants were tasked with trying to pinpoint the }\end{array}$ \\
\hline
\end{tabular}


source of the contamination by taking multiple samples of the fish from different drinking water sources.

Chen and Liu

(2020)
Chemistry

(Periodic table)
Students observed the features of the six elements in one block. The elements were based on periodic tables. Then, the students collaboratively learned to form chemical reactions by manipulating the two blocks. 